\title{
Seed Yield and Quality of Lowland Rice (Oryza sativa L.) as Influenced by Nitrogen from Organic and Chemical Sources
}

\author{
Amina Khatun ${ }^{1 *}$, Hasina Sultana ${ }^{1}$, A. B. M. Jamiul Islam ${ }^{1}$, \\ Md. Sultan Uddin Bhuiya ${ }^{2}$ and Md. Abu Saleque ${ }^{3}$ \\ ${ }^{1}$ Rice Farming Systems Division, Bangladesh Rice Research Institute, Gazipur 1701; ${ }^{2}$ Department of \\ Agronomy, Bangladesh Agricultural University, Mymensingh 2202; ${ }^{3}$ Coordinator for Advanced \\ Studies \& Research, Bangladesh Rice Research Institute, Gazipur 1701, Bangladesh \\ *Corresponding author and Email: aminabrri@gmail.com
}

Received: 20 April 2015

Accepted: 06 June 2015

\begin{abstract}
A field experiment was conducted at the Bangladesh Rice Research Institute (BRRI) experimental farm during boro season of 2010-11 to determine the effect of nitrogen from organic and chemical sources on rice seed yield and quality. Six treatments- (i) N-control, ii) Optimum dose of nitrogen (164 $\mathrm{kg} \mathrm{N} \mathrm{ha}^{-1}$ ) from urea, iii) $50 \% \mathrm{~N}$ from urea and $50 \% \mathrm{~N}$ from $\mathrm{CD}$ (cow dung), iv) $50 \% \mathrm{~N}$ from urea and $50 \% \mathrm{~N}$ from PM (poultry manure), v) $100 \% \mathrm{~N}$ from CD and vi) $100 \% \mathrm{~N}$ from PM were compared. The experiment was conducted in a randomized complete block design with four replications. Two boro varieties - BRRI dhan 28 and BRRI dhan 29 were used as test crops. The urea + PM treatment gave similar seed yields to that of urea in both the varieties. The PM treatment gave similar seed yield to that of urea + PM in BRRI dhan28, but BRRI dhan29 gave significantly lower seed yield in PM than the urea + PM. Sole cowdung or poultry manure application produced significantly lower seed yield than urea + PM treatment and sole urea application. The application of $\mathrm{N}$ from cowdung and poultry manure had no effect on rice seed quality as compared to that obtained with urea.
\end{abstract}

Keywords: Rice, poultry manure, urea, seed yield, seed quality

\section{Introduction}

Insufficiency of quality seed is one of the constraints to production of modern rice (Oryza sative L.) varieties in Bangladesh. Use of quality seed can increase rice yield by $12-15 \%$ at a given management practices (Gomosta, 2004). Nutrient management strategy in seed crop may be somewhat different from normal grain crop. Only commercial entrepreneurs grow seed crop and price of seed is always higher than that of normal food grains. Seed crop yield may be increased through proper nutrient management without sacrificing seed quality. Nitrogen $(\mathrm{N})$ is one of the most yield-limiting nutrients in rice production around the world (Fageria et al., 2008), especially in tropical Asian soils and almost every farmer has to apply the costly $\mathrm{N}$ fertilizer to get a desirable yield of rice (Saleque et al., 2004). Judicious use of fertilizers can markedly increase the yield and improve the quality of rice (Chaturvedi, 2005).

The use of organic manure in conjunction with or as an alternative to mineral fertilizer is receiving considerable attention (Singh and Gangwar, 2000; Saleque et al., 2004; Solaiman and Rabbani, 2006). The excessive application of 
chemical fertilizers has made it imperative that a portion of inorganic fertilizer be substituted by recycling organic waste. Organic manure has been proven to enhance efficiency and reduce the need for chemical fertilizers. Partial $\mathrm{N}$ substitution through the use of organic manure demonstrated significant superiority in yield over that produced by farmers (Singh and Gangwar, 2000). Application of organic manures for normal grain crop is limited because of unavailability and price of the manure, but seed growers have opportunity to apply sufficient manures if it is useful for higher yield and quality.

There is an apprehension that the application of nutrient may deteriorate seed quality, although there is little study to develop a nutrient management strategy that combine seed yield increase yet no quality is compensated. Nutrient management effect on quality rice seed production received scanty attention in rice producing countries. Under these circumstances, the present study was undertaken: i) to find out the effect of $\mathrm{N}$ from organic and inorganic sources on the seed yield and seed quality of rice and ii) to determine the seed nutrient composition of rice under varying sources of $\mathrm{N}$ application.

\section{Materials and Methods}

\subsection{Experimental site and season}

A field experiment was conducted during boro season (November-April) of 2010-2011 at the experimental farm of the Bangladesh Rice Research Institute, Gazipur, Bangladesh $\left(23^{0} 59^{\prime}\right.$ $\mathrm{N}$ latitude, $90^{\circ} 24^{\prime} \mathrm{E}$ longitude). The farm belongs to agro-ecological zone (AEZ) number 28 known as Madhupur Tract. The soil of the experimental field is Chhiata clay loam, a member of the fine, hyperthermic Vertic Endoaquept (Saleque et al., 2004). The initial soil chemical properties at 0$15 \mathrm{~cm}$ soil depth were: $\mathrm{pH} 6.1$, organic matter $2.02 \%$, total $\mathrm{N}$ content $0.07 \%$, available phosphorus (P) $10.14 \mathrm{mg} \mathrm{kg}^{-1}\left(0.5 \mathrm{M} \mathrm{NaHCO}_{3}\right.$ extracted), exchangeable potassium (K) 0.17 meq/100 g soil (Neutral $1.0 \quad \mathrm{~N} \quad \mathrm{NH}_{4} \mathrm{OAc}$ extracted), available sulfur (S) $20 \mathrm{mg} \mathrm{kg} \mathrm{kg}^{-1}$ $\left[\mathrm{Ca}\left(\mathrm{H}_{2} \mathrm{PO}_{4}\right)_{2}\right.$ extracted], and available zinc ( $\left.\mathrm{Zn}\right)$ $2.8 \mathrm{mg} \mathrm{kg}^{-1}(0.01 \mathrm{~N} \mathrm{HCl}$ extracted $)$.

\subsection{Design and treatments}

The experiment involved two factors, rice variety and $\mathrm{N}$ sources. Two rice varieties BRRI dhan 28 and BRRI dhan29 were grown under irrigated conditions during boro season of 201011. BRRI dhan 28 is a short duration high yielding boro variety (growth duration 145 days) and BRRI dhan29 is a long duration high yielding boro variety (growth duration 160 days). Six N treatments were: (1) N control (0 kg $\left.\mathrm{N} \mathrm{ha}^{-1}\right)$, (2) Optimum dose of nitrogen from urea (164 $\left.\mathrm{kg} \mathrm{N} \mathrm{ha}^{-1}\right)$, (3) $50 \% \mathrm{~N}$ from urea and $50 \% \mathrm{~N}$ from cowdung (CD), (4) $50 \% \mathrm{~N}$ from urea and $50 \% \mathrm{~N}$ from poultry manure (PM), (5) $100 \% \mathrm{~N}$ from $\mathrm{CD}$ and (6) $100 \% \mathrm{~N}$ from from PM. The experiment was conducted in a randomized complete block design with four replications.

\subsection{Crop husbandry operations}

Rice was transplanted in first week of January with 40-day-old seedlings and harvested in May. Two/three rice seedlings were transplanted maintaining $20 \times 20 \mathrm{~cm}$ spacing. The seed rate for rice was $30 \mathrm{~kg} \mathrm{ha}^{-1}$. Unit plot size was $5-\times 4$ m. All plots were surrounded by soil levees 30 $\mathrm{cm}$ high to avoid $\mathrm{N}$ contamination between plots. Nitrogen was top dressed as urea in three equal splits: 20, 35 and 50 days after transplanting (DAT) for BRRI dhan 28 and 20, 35 and 55 DAT for BRRI dhan29. Phosphorus (P), potassium $(\mathrm{K})$, sulfur (S) and zinc ( $\mathrm{Zn})$ were applied as triple super phosphate, muriate of potash, gypsum and zinc sulphate, respectively, during final land preparation. The cowdung (CD) and poultry manure (PM) were applied on a dry weight basis and mixed well with the soil, by manual digging, about two weeks before transplanting of rice. The CD was collected from the BRRI cattle shed and PM was collected from a nearby poultry farm. Nutrient concentrations in $\mathrm{CD}$ and $\mathrm{PM}$ were determined. The $\mathrm{N}, \mathrm{P}, \mathrm{K}$ and $\mathrm{S}$ concentration in $\mathrm{CD}$ (oven dry basis) were 0.85 , $0.33,0.52$ and, $0.08 \%$ and those in PM were $2.28,1.03,1.20$ and $0.24 \%$, respectively. 


\subsection{Measurements}

At maturity the crop was harvested manually at $15 \mathrm{~cm}$ above ground level. However, 16 hills from each plot were harvested at the ground level for measuring yield components and straw yield. The seed yield was recorded at $12 \%$ moisture content and straw yield as oven dry basis following standard procedures as described by Yoshida et al. (1976). Rice plants from $5 \mathrm{~m}^{2}$ area of the middle of each plot were harvested at ground level and threshed. The grains were dried in sunlight and winnowed before weighing and the seed yield was converted into $\mathrm{tha}^{-1}$, using the following formula:

$$
\text { Adjusted weight }=\frac{W \times\left(100-M_{1}\right)}{\left(100-M_{2}\right)} \times 100
$$

Where, $\mathrm{W}$ is the fresh weight of the grains and $\mathrm{M}_{1}$ and $\mathrm{M}_{2}$ are the fresh and adjusted moisture percents of the grain, respectively.

Harvest index (HI) was computed in percentage as follows:

$$
H I=\left(\frac{\text { Seed yield }}{\text { Seed yield }+ \text { Straw yield }}\right) \times 100
$$

Sterility was calculated using the following formula:

Sterility $(\%)=\left(\frac{\text { Sterile spikelets }}{\text { Sterile spikelets }+ \text { filled grains }}\right) \times 100$

\subsection{Seed quality assessment}

The quality of the rice seeds were assessed by seed germination, seed viability and seedling vigour test. Seedling vigour was tested following two methods: 1) speed of germination and 2) seedling length measurement (Agrawal, 2005). Germination count was made according to ISTA (2006). The $\mathrm{N}, \mathrm{P}, \mathrm{K}$ and $\mathrm{Mg}$ concentrations in seed grain were determined according to Yoshida et al., (1976). Seed protein content was calculated by multiplying the nitrogen content $(\%)$ in seeds by a factor of 5.95 (Juliano, 1972).

\subsection{Data analysis}

Analysis of variance (ANOVA) of the measured parameters was performed and the treatment means were compared using Least Significant Difference (LSD) at the 5\% level of probability (Gomez and Gomez, 1984). The significance test of the regression analysis was done following Statcal (2012).

\section{Results and Discussion}

\subsection{Yield components}

3.1.1. Tiller production

Nitrogen sources $(\mathrm{N})$ and variety $(\mathrm{V})$ interactions and the individual effects of $\mathrm{N}$ and $\mathrm{V}$ on tiller production were significant $(\mathrm{P}<0.01)$ (Table 1). The $\mathrm{N}$ control plots produced tiller number of 224 and 218 per $\mathrm{m}^{2}$ in BRRI dhan 28 and BRRI dhan29, respectively. In BRRI dhan 28 the absolute urea treatment increased the number of tiller to 321 per $\mathrm{m}^{2}$ followed by urea+ $\mathrm{CD}$ treatment $\left(313 \mathrm{~m}^{-2}\right)$. The absolute urea treatment gave significantly higher tiller in comparison to that of absolute CD treatment and absolute PM treatment. In BRRI dhan29, the absolute urea treatment gave the highest number of tillers (383 $\left.\mathrm{m}^{-2}\right)$ followed by urea+ PM treatment $\left(373 \mathrm{~m}^{-2}\right)$. The absolute CD treatment gave significantly lower tiller production compared to that of urea+ $\mathrm{CD}$ treatment. Irrespective of $\mathrm{N}$ sources, BRRI dhan 29 produced significantly higher number of tillers compared to BRRI dhan28 except $\mathrm{N}$ control and absolute CD treatment.

\subsubsection{Panicle production}

Nitrogen sources $(\mathrm{N})$ and variety $(\mathrm{V})$ interactions and the individual effect of $\mathrm{N}$ for panicle production were significant $(\mathrm{P}<0.01)$ (Table 1$)$. In BRRI dhan28, the urea treatment gave the highest number of panicle followed by urea+ CD treatment and urea+ PM treatment. In BRRI dhan29, the urea treatment gave the highest number of panicles followed by urea+ PM treatment. All the treatments produced significantly higher number of panicles in comparison to $\mathrm{N}$ control treatment as well as BRRI dhan28. Under urea treatment, BRRI dhan29 gave significantly higher number of panicles than BRRI dhan28. Under urea+ CD treatment, urea+ PM treatment and absolute PM treatment, BRRI dhan29 gave significantly higher number of panicles compared to BRRI dhan28. BRRI dhan28 and BRRI dhan29 produced similar number of panicles Under $\mathrm{N}$ control treatment. 
Table 1. Tiller and panicle production and yields of two rice varieties as influenced by different nitrogen sources

\begin{tabular}{lcccc}
\hline $\begin{array}{l}\text { N sources (N) } \\
\left(\mathrm{kg} \mathrm{ha}^{-1}\right)\end{array}$ & $\begin{array}{c}\text { Tiller m }^{-2} \\
(\text { No. })\end{array}$ & $\begin{array}{c}\text { Panicle }^{-2} \\
(\text { No. })\end{array}$ & $\begin{array}{c}\text { Seed yield } \\
\left(\mathrm{t} \mathrm{ha}^{-1}\right)\end{array}$ & $\begin{array}{c}\text { Straw yield } \\
\left(\mathrm{t} \mathrm{ha}^{-1}\right)\end{array}$ \\
\hline BRRI dhan28 & & & & \\
Control & $224 \mathrm{c}$ & $214 \mathrm{c}$ & $3.80 \mathrm{~d}$ & $4.22 \mathrm{~d}$ \\
Urea & $321 \mathrm{a}$ & $309 \mathrm{a}$ & $6.69 \mathrm{a}$ & $6.94 \mathrm{a}$ \\
Urea + CD & $313 \mathrm{a}$ & $299 \mathrm{a}$ & $6.07 \mathrm{~b}$ & $6.33 \mathrm{~b}$ \\
CD & $261 \mathrm{~b}$ & $250 \mathrm{~b}$ & $4.61 \mathrm{c}$ & $4.85 \mathrm{c}$ \\
Urea + PM & $301 \mathrm{ab}$ & $286 \mathrm{a}$ & $6.46 \mathrm{a}$ & $6.52 \mathrm{~b}$ \\
PM & $274 \mathrm{~b}$ & $265 \mathrm{~b}$ & $6.46 \mathrm{a}$ & $6.61 \mathrm{ab}$ \\
\hline BRRI dhan29 & & & & \\
Control & $218 \mathrm{c}$ & $209 \mathrm{c}$ & $4.53 \mathrm{~d}$ & $5.02 \mathrm{~d}$ \\
Urea & $383 \mathrm{a}$ & $361 \mathrm{a}$ & $7.54 \mathrm{ab}$ & $7.73 \mathrm{a}$ \\
Urea + CD & $361 \mathrm{a}$ & $346 \mathrm{a}$ & $7.35 \mathrm{~b}$ & $7.66 \mathrm{a}$ \\
CD & $256 \mathrm{~b}$ & $243 \mathrm{~b}$ & $5.63 \mathrm{c}$ & $5.76 \mathrm{c}$ \\
Urea + PM & $373 \mathrm{a}$ & $347 \mathrm{a}$ & $7.63 \mathrm{a}$ & $7.94 \mathrm{a}$ \\
PM & $362 \mathrm{a}$ & $346 \mathrm{a}$ & $7.10 \mathrm{~b}$ & $7.32 \mathrm{~b}$ \\
\hline CV $(\%)$ & 9.5 & 9.7 & 4.0 & 5.0 \\
\hline
\end{tabular}

Table 2. Different yield parameters of two rice varieties as influenced by different nitrogen sources

\begin{tabular}{lccc}
\hline N source (N) $\left(\mathrm{kg} \mathrm{ha}^{-1}\right)$ & Grains panicle $^{-1}$ & 1000 grain wt $(\mathrm{g})$ & Harvest Index \\
BRRI dhan28 & & & \\
Control & $78 \mathrm{~b}$ & $22 \mathrm{a}$ & $0.44 \mathrm{c}$ \\
Urea & $90 \mathrm{a}$ & $22 \mathrm{a}$ & $0.45 \mathrm{~b}$ \\
Urea + CD & $79 \mathrm{~b}$ & $22 \mathrm{a}$ & $0.45 \mathrm{~b}$ \\
CD & $87 \mathrm{a}$ & $22 \mathrm{a}$ & $0.45 \mathrm{~b}$ \\
Urea + PM & $86 \mathrm{a}$ & $22 \mathrm{a}$ & $0.46 \mathrm{ab}$ \\
PM & $88 \mathrm{a}$ & $22 \mathrm{a}$ & $0.46 \mathrm{ab}$ \\
\hline BRRI dhan29 & & & \\
Control & $92 \mathrm{~b}$ & $23 \mathrm{ab}$ & $0.44 \mathrm{c}$ \\
Urea & $113 \mathrm{a}$ & $24 \mathrm{a}$ & $0.46 \mathrm{ab}$ \\
Urea + CD & $113 \mathrm{a}$ & $24 \mathrm{a}$ & $0.45 \mathrm{bc}$ \\
CD & $100 \mathrm{~b}$ & $24 \mathrm{a}$ & $0.46 \mathrm{ab}$ \\
Urea + PM & $123 \mathrm{a}$ & $24 \mathrm{a}$ & $0.45 \mathrm{bc}$ \\
PM & $123 \mathrm{a}$ & $22 \mathrm{~b}$ & $0.46 \mathrm{ab}$ \\
\hline CV $(\%)$ & 9.6 & 5.6 & 1.2 \\
\hline
\end{tabular}

\subsubsection{Grains panicle ${ }^{-1}$}

Nitrogen sources $(\mathrm{N})$ and variety $(\mathrm{V})$ interactions and the individual effect of $\mathrm{N}$ for grains panicle ${ }^{-1}$ were significant $(\mathrm{P}<0.05)$ for the number of grains per panicle (Table 2). The application of
$\mathrm{N}$ increased grains per panicle significantly than that by in the $\mathrm{N}$ control in BRRI dhan29. The difference in grains per panicle between BRRI dhan 28 and BRRI dhan 29 was larger in urea + $\mathrm{CD}$, urea + PM and PM compared to that in urea treatment. 


\subsubsection{0-grain weight}

The individual effect of nitrogen sources $(\mathrm{N})$ and the interactions of nitrogen sources $(\mathrm{N})$ and variety (V) were insignificant for 1000-grain weight (TGW). BRRI dhan28, produced TGW of $22 \mathrm{~g}$ in all $\mathrm{N}$ treatments. In BRRI dhan29, it ranged from 22-24 $\mathrm{g}$ among the $\mathrm{N}$ treatments. The individual effect of $\mathrm{V}$ was significant $(\mathrm{P}<0.01)$ for TGW. BRRI dhan29 gave higher TGW than BRRI dhan28 except in absolute PM treatment. The absolute PM treatment gave $22 \mathrm{~g}$ TGW in BRRI dhan29 (Table 2).

\subsubsection{Harvest index (HI)}

The main effect of nitrogen sources $(\mathrm{N})$ was highly significant $(\mathrm{P}<0.01)$, but the interaction effects of $\mathrm{N}$ and $\mathrm{V}$ and the main effect of $\mathrm{V}$ were insignificant $(\mathrm{P}>0.05)$ for harvest index (Table 2). In both BRRI dhan 28 and BRRI dhan 29 the $\mathrm{HI}$ varied from 0.44 to 0.46 . The $\mathrm{N}$ control plots gave the lowest $\mathrm{HI}$ in both the varieties. The application of $\mathrm{N}$ increased HI slightly. The urea+ PM treatment and absolute PM treatment gave the higher $\mathrm{HI}$ followed by absolute urea treatment, urea+ CD treatment and absolute CD treatment. In BRRI dhan29, different scenario was observed for HI. The absolute urea treatment, absolute CD treatment and absolute PM treatment gave the higher HI (0.46) followed by urea+ CD treatment and urea+ PM treatment (0.45).

\subsection{Seed yield}

Interaction of nitrogen sources $(\mathrm{N})$ and variety (V) for seed yield demonstrated insignificant ( $\mathrm{P}>0.05$ ) difference (Table 1). However, both the varieties and sources of $\mathrm{N}$, individually, produced significantly different seed yield $(\mathrm{P}<0.01)$. BRRI dhan29 out yielded BRRI dhan28 at all $\mathrm{N}$ treatments including the control and application of $\mathrm{N}$ through organic or inorganic sources increased seed yield dramatically in both the varieties (Table 1). In the control plots, BRRI dhan28 gave yield of $3.80 \mathrm{t} \mathrm{ha}^{-1}$ compared to $4.53 \mathrm{t} \mathrm{ha}^{-1}$ in BRRI dhan29. Application of $\mathrm{N}$ through urea increased seed yield over the $\mathrm{N}$ control by about $2.89 \mathrm{t} \mathrm{ha}^{-1}$ in BRRI dhan28 and $3.01 \mathrm{t} \mathrm{ha}^{-1}$ in BRRI dhan29.
Sharing the $\mathrm{N}$ between urea and $\mathrm{CD}$ decreased yield significantly in both the varieties compared to that obtained with urea. But the urea $+\mathrm{CD}$ treatment gave a yield advantage of 2.27 and $2.82 \mathrm{t} \mathrm{ha}^{-1}$, compared to control, in BRRI dhan28 and BRRI dhan29, respectively. When the entire $\mathrm{N}$ was applied solely through $\mathrm{CD}$, seed yield decreased to 4.61 and $5.63 \mathrm{t} \mathrm{ha}^{-1}$ in BRRI dhan28 and BRRI dhan29, respectively (Table 1). These yields were statistically lowest among the $\mathrm{N}$ treatments in both the varieties, however, significantly higher than that obtained with the inherent soil N. The urea + PM treatment gave similar yield to that of urea in both the varieties, however, BRRI dhan29 gave about $1.17 \mathrm{t} \mathrm{ha}^{-1}$ higher yield than BRRI dhan28. The PM treatment gave similar yield to that with urea + PM in BRRI dhan28, but BRRI dhan29 gave significantly lower in PM than the urea + PM.

\subsection{Straw yield}

The individual effect of nitrogen source $(\mathrm{N})$ for straw yield was highly significant $(\mathrm{P}<0.01)$ (Table 1). In BRRI dhan28, the absolute urea treatment gave the higher straw yield $\left(6.94 \mathrm{t} \mathrm{ha}^{-1}\right)$ followed by absolute PM treatment $\left(6.61 \mathrm{t} \mathrm{ha}^{-1}\right)$ and urea+ PM treatment $\left(6.52 \mathrm{t} \mathrm{ha}^{-1}\right)$. The absolute PM treatment gave significantly higher straw yield than that of absolute CD treatment. On the other hand, absolute urea treatment gave significantly higher straw yield $\left(6.94 \mathrm{t} \mathrm{ha}^{-1}\right)$ than that of urea+ CD treatment $\left(6.33 \mathrm{t} \mathrm{ha}^{-1}\right)$. The $\mathrm{N}$ control treatment gave the lowest straw yield (4.22 $\mathrm{t} \mathrm{ha}^{-1}$ ). In BRRI dhan29, the urea+ PM treatment gave higher straw yield $\left(7.94 \mathrm{t} \mathrm{ha}^{-1}\right)$ followed by urea treatment $\left(7.73 \mathrm{t} \mathrm{ha}^{-1}\right)$ and urea+ CD treatment $\left(7.66 \mathrm{t} \mathrm{ha}^{-1}\right)$. The absolute PM treatment gave significantly lower straw yield $\left(7.32 \mathrm{t} \mathrm{ha}^{-1}\right)$ in comparison to urea+ PM treatment $\left(7.94 \mathrm{t} \mathrm{ha}^{-1}\right)$.

In $\mathrm{N}$ control treatment, BRRI dhan29 gave significantly higher straw yield $\left(5.02 \mathrm{t} \mathrm{ha}^{-1}\right)$ in comparison to BRRI dhan28 (4.22 $\left.\mathrm{t} \mathrm{ha}^{-1}\right)$. In urea treatment, BRRI dhan 29 gave the highest straw yield in comparison to BRRI dhan28. Under urea+ CD treatment and absolute CD treatments, BRRI dhan29 gave significantly higher straw 
yields in comparison to BRRI dhan28. Under urea + PM treatment, BRRI dhan29 gave significantly higher straw yield (7.94 $\left.\mathrm{t} \mathrm{ha}^{-1}\right)$ compared to BRRI dhan28 (6.52 $\left.\mathrm{t} \mathrm{ha}^{-1}\right)$. A similar trend of straw yield was also observed in absolute PM treatment.

\subsection{Seed quality and nitrogen sources 3.4.1. Seed Germination}

The nitrogen sources (N) and variety (V) interactions and the individual effect of $\mathrm{N}$ showed insignificant on seed germination. But the individual effect of $\mathrm{V}$ on seed germination was highly significant $(\mathrm{p}<0.01)$. In BRRI dhan28, all other treatments except urea $+C D$ treatment gave statistically similar germination percentage (Table 3 ). The urea $+\mathrm{CD}$ treatment gave the lowest germination (\%). In BRRI dhan29, all the treatments gave statistically similar germination. Under $\mathrm{N}$ control, absolute urea, urea $+\mathrm{CD}$ and absolute PM treatment, BRRI dhan29 gave significantly higher germination (\%) compared to BRRI dhan 28 .

\subsubsection{Viability and vigor}

The nitrogen sources $(\mathrm{N})$ and variety (V) interactions showed insignificant effect $(p>0.05)$ on seed viability, speed of germination and seedling vigor. Seed viability was determined by germination test. The individual effect of $\mathrm{N}$ on speed of germination was also insignificant $(\mathrm{p}>0.05)$.

In BRRI dhan28, all the treatments showed statistically similar speed of germination. A similar scenario was also observed in BRRI dhan29.The individual effect of $\mathrm{V}$ on speed of germination was highly significant $(p<0.01)$ (Table 3). In all other treatments except absolute CD treatment, BRRI dhan 29 gave significantly higher speed of germination compared to BRRI dhan28. The individual effects of $\mathrm{N}$ and $\mathrm{V}$ on vigor index were also insignificant $(\mathrm{p}>0.05)$. In BRRI dhan28, all the treatments gave statistically similar vigor index. A similar scenario was also observed in BRRI dhan29. Vigour testing is important because it often gives a better prediction of field performance and is a more sensitive indicator of seed quality than the standard germination test (Younis et al., 1990). Hossain et al. (2009) found significant effectof varieties but the interaction effect of fertilizer and variety was insignificant. A significant number of scientist reported that different sources of organic manures improve the soil fertility, yield and quality of rice (Pandey et al., 1999; Hemalatha et al., 2004).

Table 3. Effect of different nitrogen sources on seed quality of BRRI dhan 28 and BRRI dhan29

\begin{tabular}{lccc}
\hline N-Source $(\mathrm{N})\left(\mathrm{kg} \mathrm{ha}^{-1}\right)$ & Germination $(\%)$ & Speed of germination & Vigour Index \\
\hline BRRI dhan28 & & & \\
Control & $89 \mathrm{ab}$ & $17.25 \mathrm{a}$ & $749.79 \mathrm{ab}$ \\
Urea & $88 \mathrm{ab}$ & $17.09 \mathrm{a}$ & $777.31 \mathrm{ab}$ \\
Urea + CD & $86 \mathrm{~b}$ & $17.41 \mathrm{a}$ & $721.47 \mathrm{~b}$ \\
CD & $92 \mathrm{a}$ & $17.92 \mathrm{a}$ & $794.35 \mathrm{ab}$ \\
Urea + PM & $90 \mathrm{ab}$ & $17.41 \mathrm{a}$ & $857.38 \mathrm{a}$ \\
PM & $91 \mathrm{a}$ & $17.82 \mathrm{a}$ & $800.20 \mathrm{ab}$ \\
\hline BRRI dhan29 & & & \\
Control & $94 \mathrm{a}$ & $18.24 \mathrm{a}$ & $691.12 \mathrm{~b}$ \\
Urea & $91 \mathrm{a}$ & $17.82 \mathrm{a}$ & $759.33 \mathrm{ab}$ \\
Urea + CD & $92 \mathrm{a}$ & $18.01 \mathrm{a}$ & $833.85 \mathrm{a}$ \\
CD & $94 \mathrm{a}$ & $18.27 \mathrm{a}$ & $727.07 \mathrm{ab}$ \\
Urea + PM & $92 \mathrm{a}$ & $17.92 \mathrm{a}$ & $716.69 \mathrm{~b}$ \\
PM & $95 \mathrm{a}$ & $18.51 \mathrm{a}$ & $836.78 \mathrm{a}$ \\
\hline CV $(\%)$ & 5.9 & 6.1 & 18.5 \\
\hline
\end{tabular}


Table 4. Nutrient contents of seeds of two rice varieties as influenced by different nitrogen sources

\begin{tabular}{lccccc}
\hline N-Source $(\mathrm{N})\left(\mathrm{kg} \mathrm{ha}^{-1}\right)$ & $\mathrm{N} \%$ & $\mathrm{P} \%$ & $\mathrm{~K} \%$ & $\mathrm{Mg} \%$ & Protein\% \\
\hline BRRI dhan28 & & & & & \\
Control & $0.92 \mathrm{~b}$ & $0.30 \mathrm{c}$ & $0.26 \mathrm{ab}$ & $0.085 \mathrm{~b}$ & $5.46 \mathrm{~b}$ \\
Urea & $0.97 \mathrm{ab}$ & $0.38 \mathrm{ab}$ & $0.27 \mathrm{a}$ & $0.091 \mathrm{a}$ & $5.75 \mathrm{a}$ \\
Urea + CD & $0.94 \mathrm{~b}$ & $0.36 \mathrm{~b}$ & $0.24 \mathrm{~b}$ & $0.085 \mathrm{~b}$ & $5.58 \mathrm{~b}$ \\
$\mathrm{CD}$ & $0.94 \mathrm{~b}$ & $0.36 \mathrm{~b}$ & $0.25 \mathrm{ab}$ & $0.086 \mathrm{~b}$ & $5.60 \mathrm{~b}$ \\
Urea + PM & $1.02 \mathrm{a}$ & $0.41 \mathrm{a}$ & $0.26 \mathrm{ab}$ & $0.087 \mathrm{~b}$ & $6.08 \mathrm{a}$ \\
PM & $0.92 \mathrm{~b}$ & $0.35 \mathrm{~b}$ & $0.25 \mathrm{ab}$ & $0.087 \mathrm{~b}$ & $5.50 \mathrm{~b}$ \\
BRRI dhan29 & & & & & \\
Control & $0.87 \mathrm{~b}$ & $0.44 \mathrm{a}$ & $0.26 \mathrm{ab}$ & $0.087 \mathrm{a}$ & $5.16 \mathrm{c}$ \\
Urea & $0.92 \mathrm{~b}$ & $0.35 \mathrm{~b}$ & $0.24 \mathrm{~b}$ & $0.087 \mathrm{a}$ & $5.48 \mathrm{c}$ \\
Urea + CD & $0.91 \mathrm{~b}$ & $0.34 \mathrm{~b}$ & $0.23 \mathrm{~b}$ & $0.083 \mathrm{~b}$ & $5.40 \mathrm{c}$ \\
CD & $1.09 \mathrm{a}$ & $0.45 \mathrm{a}$ & $0.24 \mathrm{~b}$ & $0.085 \mathrm{ab}$ & $6.50 \mathrm{a}$ \\
Urea + PM & $0.92 \mathrm{~b}$ & $0.28 \mathrm{c}$ & $0.26 \mathrm{ab}$ & $0.086 \mathrm{ab}$ & $5.50 \mathrm{c}$ \\
PM & $1.03 \mathrm{a}$ & $0.41 \mathrm{a}$ & $0.24 \mathrm{~b}$ & $0.086 \mathrm{ab}$ & $6.10 \mathrm{~b}$ \\
\hline CV $(\%)$ & 6.8 & 11.5 & 7.9 & 10.8 & 6.8 \\
\hline
\end{tabular}

\subsection{Seed nutrient content}

\subsubsection{Seed nitrogen content}

The nitrogen sources (N) and variety (V) interactions and the main effect of $\mathrm{N}$ in relation to seed $\mathrm{N}$ concentration were highly significant $(\mathrm{P}<0.01)$. But the main effect of $\mathrm{V}$ on seed $\mathrm{N}$ concentration was not significant $(\mathrm{P}>0.05)$ (Table 4). In BRRI dhan28, the seed $\mathrm{N}$ concentration varied from 0.92 to $1.02 \%$ among the $\mathrm{N}$ sources. The urea+ PM treatment gave the higher seed $\mathrm{N}$ concentration $(1.02 \%)$ followed by urea treatment $(0.97 \%)$. The urea+ CD treatment and the absolute $\mathrm{CD}$ treatment gave similar seed $\mathrm{N}$ concentration $(0.94 \%)$. The lowest seed $\mathrm{N}$ concentration $(0.92 \% \mathrm{~N})$ was observed in absolute PM treatment. However, the value was similar with that in $\mathrm{N}$ control treatment. In BRRI dhan29, the seed $\mathrm{N}$ concentration varied from 0.87 to $1.09 \%$ among different $\mathrm{N}$ sources. The absolute $\mathrm{CD}$ treatment gave the highest seed N\% (1.09\%) followed by absolute PM treatment (1.03\%). The absolute CD treatment $(1.09 \%)$ and the absolute PM treatment $(1.03 \%)$ gave significantly higher seed $\mathrm{N}$ concentration in comparison to all other $\mathrm{N}$ treatments. The lowest seed $\mathrm{N}$ concentration $(0.87 \%)$ was obtained from $\mathrm{N}$ control treatment. Under absolute CD treatment and absolute PM treatment, BRRI dhan29 produced significantly higher seed $\mathrm{N} \%$ compared to BRRI dhan 28 .

\subsubsection{Seed phosphorus content}

The N x V interactions and the individual effect of $\mathrm{N}$ for seed $\mathrm{P}$ concentration were significant $(\mathrm{P}<0.01)$. In BRRI dhan28, the urea+ $\mathrm{PM}$ treatment gave higher seed $\mathrm{P} \%(0.41 \%)$ followed by urea treatment $(0.38 \%)$. The urea treatment, urea+ $\mathrm{CD}$ treatment and absolute $\mathrm{CD}$ treatment $(0.36 \%)$ gave statistically similar seed P \% (0.38\%). In BRRI dhan29, the absolute CD treatment gave the highest seed P \% $(0.45 \%)$ followed by absolute PM treatment $(0.41 \%)$. The absolute $\mathrm{CD}$ treatment gave significantly higher seed $\mathrm{P}$ concentration in comparison to urea treatment, urea+ CD treatment and urea+ PM treatment. The absolute PM treatment also gave significantly higher seed $\mathrm{P} \%$ in comparison to all other treatments. The $\mathrm{N}$ control treatment gave the lowest seed $\mathrm{P} \%$ in both the varieties (Table 4).

\subsubsection{Seed potassium content}

The $\mathrm{N} \times \mathrm{V}$ interactions in relation to seed $\mathrm{K}$ concentration were not significant $(\mathrm{P}>0.05)$. But the main effect of $\mathrm{N}$ and $\mathrm{V}$ in relation to seed $\mathrm{K}$ $\%$ was significant $(\mathrm{P}<0.05)$. In BRRI dhan28, the urea treatment gave the highest seed $\mathrm{K}$ 
concentration $(0.27 \%)$ followed by urea+ PM treatment and $\mathrm{N}$ control treatment $(0.26 \%)$. The urea+ CD treatment gave the lowest seed $\mathrm{K}$ concentration $(0.24 \%)$. The urea+ PM treatment and $\mathrm{N}$ control treatment gave the higher $\mathrm{K}$ concentration $(0.26 \%)$. Under urea treatment, BRRI dhan 28 gave significantly higher seed $\mathrm{K}$ \% $(0.27 \%)$ compared to BRRI dhan28 (0.24\%). But under urea+ $\mathrm{CD}$, absolute $\mathrm{CD}$ and absolute PM treatments, BRRI dhan28 and BRRI dhan29 gave statistically similar seed $\mathrm{K}$ concentration (Table 4).

\subsubsection{Seed magnesium content}

In BRRI dhan28, the seed $\mathrm{Mg}$ concentration varied from 0.085 to $0.091 \%$ among the $\mathrm{N}$ sources. The highest seed $\mathrm{Mg}$ concentration $(0.091 \%)$ was obtained from urea treatment followed by urea+ PM treatment $(0.087 \%)$ and absolute PM treatment $(0.087 \%)$ (Table 4$)$. In BRRI dhan29, the seed Mg concentration ranged from 0.83 to $0.087 \%$ among different $\mathrm{N}$ sources. Among different $\mathrm{N}$ sources the seed $\mathrm{Mg}$ concentration showed statistically similar performance. BRRI dhan28 and BRRI dhan29 gave statistically similar seed $\mathrm{Mg}$ concentration irrespective of different $\mathrm{N}$ treatments.

\subsubsection{Seed protein content}

The $\mathrm{N} x \mathrm{~V}$ interactions in relation to seed protein (\%) were highly significant $(\mathrm{P}<0.01)$. The individual effect of $\mathrm{N}$ for protein $(\%)$ was also significant $(\mathrm{P}<0.05)$. In $\mathrm{BRRI}$ dhan 28 , the seed protein concentration varied from 5.46 to $6.08 \%$ among different $\mathrm{N}$ sources. The highest seed protein $(6.08 \%)$ was observed in urea+ PM treatment followed by urea treatment $(5.75 \%)$ (Table 4). The urea+ PM treatment showed significantly higher seed protein $\%$ in comparison to absolute PM treatment. The lowest seed protein (\%) was obtained from $\mathrm{N}$ control treatment $(5.46 \%)$. In BRRI dhan29, the seed protein \% varied from 5.16 to $6.50 \%$ among different $\mathrm{N}$ sources. The highest seed protein concentration $(6.50 \%)$ was obtained from absolute CD treatment followed by absolute PM treatment $(6.10 \%)$. The $\mathrm{N}$ control treatment gave the lowest seed protein concentration
(5.16\%). BRRI dhan28 and BRRI dhan29 gave similar seed protein $\%$ under $\mathrm{N}$ control treatment, urea treatment and urea+ $\mathrm{CD}$ treatment. But under absolute CD treatment, BRRI dhan29 gave significantly higher seed protein \% in comparison to BRRI dhan 28.

Hossain et al. (2009) reported fertilizers had significant influence on protein percentage in brown rice of BRRI dhan28. They obtained the highest protein $(7.78 \%)$ in rice with the recommended chemical fertilizer (NPKSZn) dose and the lowest $(6.80 \%)$ was in the control. Blumenthal et al. (2008) observed that nitrogen influence amino acid composition of protein and in turn its nutritional quality in rice. Uppal and Bali (1997) reported that protein content increased significantly with the increased dose of nitrogen in rice. Sikdar et al. (2008) reported significant varietal difference in $\mathrm{N}$ content, $\mathrm{N}$ uptake, protein and aroma of rice grain. Varietal differences in rice on $\mathrm{N}$ content and consequently protein percentage have been reported frequently (Mannan, 2005; Saleque et al., 2005). Total soluble protein of freshly harvested rice seed influenced significantly by planting time, $\mathrm{N}$ level and mode of $\mathrm{N}$ application. Total soluble protein ranged from 5.12 to $9.27 \mathrm{mg} \mathrm{g}^{-1}$ which is an agreement with the findings of Sinclair and De Wit (1975) who found 8 to $16 \%$ proteins in cereal seed.

\section{Conclusions}

Cowdung and poultry manure might become alternative sources of nitrogen for rice seed production. Poultry manure in combination with urea might be an alternative option to grow quality rice seed without sacrificing yield. Nitrogen application to rice seed crop either from chemical or organic sources did not impair seed quality in terms of germination, viability and vigor. However, a slight difference in the seed nutrient contents due to nitrogen sources resulted in little variation in the seed qualities of the ricevarieties. Further investigation on the effect of $\mathrm{P}$ and $\mathrm{K}$ fertilization from organic and chemical sources on rice seed quality could be made. 


\section{References}

Agrawal, R. L. 2005. Seed Technology. Oxford \& IBH Publishing Co. Pvt. Ltd., New Delhi, India, 565-590 pp.

Blumenthal, J., Baltensperger, D., Cassman, K.G., Mason, S., Pavlista, A. 2008. Importance and effect of nitrogen on crop quality and health. Agronomy and Horticulture Department, AgronomyFaculty Publications, University of Nebraska-Lincoln.

Chaturvedi, I. 2005. Effect of nitrogen fertilizers on growth, yield and quality of hybrid rice. Journal of Central European Agriculture, 6: 611-618.

Fageria, N. K., Santos, A. B., Cutrim, V. A. 2008. Dry matter and yield of lowland rice genotypes as influence by nitrogen fertilization. Journal of Plant Nutrition, 31: 788-795.

Gomez, K. A. and Gomez, A. A. 1984. Statistical procedure for agricultural research $\left(2^{\text {nd }}\right.$ ed.). John Willey and Sons, Singapore, 28-192 pp.

Gomosta, A. R. 2004. Emerging technologies for sustainable rice production in Bangladesh. Keynote presented in the $20^{\text {th }} \mathrm{HYV}$ workshop, 15-17 March 2004, BRRI, Gazipur.

Hemalatha, M., Thirumurugan, V., Balasubramanian, R. 2004. Effect of organic sources of nitrogen on productivity, quality of rice (Oryza sativa) and soil fertilityin single crop wetlands. Indian Journal of A gronomy, 45: 564-567.

Hossain, M. F., Bhuiya, M. S. U., Ahmed, M., Mian, M. H. 2009. Effect of organic and inorganic fertilizer on the milling and physicochemical properties of aromatic rice. Thai Journal of Agricultural Science, 42: 213-218.
ISTA. 2006. International rules for seed testing. International Seed Testing Association, Bassersdorf, Switzerland.

Juliano, B. O. 1972. Physicochemical properties of starch and protein in relation to grain quality and nutritional value of rice. In: International Rice Research Institute, Rice Breeding, 389-405 pp.

Mannan, M. A. 2005. Effect of planting date, nitrogen fertilization and water stress on growth, yield and quality of fine rice. $P h$ $D$ Thesis, Department of Agronomy, Bangladesh Agricultural University, Mymensingh, Bangladesh, 94-111 pp.

Pandey, N., Sarawgi, A. K., Rastogi, N. K., Tripathi, R. S. 1999. Effect of farmyard manure and chemical $\mathrm{N}$ fertilizer on grain yield and quality of scented rice (Oryza sativa) varieties. Indian Journal of Agricultural Sciences, 69: 621-623.

Saleque, M. A., Abedin, M. J., Bhuiyan, N. I., Zaman, S. K., Panaullah, G. M. 2004. Long-term effects of inorganic and organic fertilizer sources on yield and nutrient accumulation of lowland rice. Field Crops Research, 86: 53-65.

Saleque, M. A., Naher, U. A., Choudhury, N. N., Hossain, A. T. M. S. 2005. Varietyspecific nitrogen fertilizer recommendation for lowland rice. Communication in Soil Science, 35: 18911903.

Sikdar, M. S. I., Rahman, M. M., Islam, M. S., Yeasmin, M. S., Akhter, M. M. 2008. Effect of nitrogen level on aromatic rice varieties and soil fertility status. International Journal of Sustainable Crop Production, 3: 49-54.

Sinclair, T. R, De Wit C. T. 1975. Photosynthate and nitrogen requirements for food production by various crops. Science, 189: 565-567. 
Singh, P., Gangwar, B. 2000. Nitrogen substitution through FYM in maize-wheat cropping sequence under irrigated conditions. In: Proc. of International Conference on Managing Natural Resources for Sustainable Agricultural Production in the $21^{\text {st }}$ Century, New Delhi, 881-882 pp.

Solaiman, A. R. M., Rabbani, M. G. 2006. Effects of N P K S and cow dung on growth and yield of tomato. Bulletin Institute of Tropical Agriculture, Kyushu University, 29: 31-37.

Statcal.2012.http://www.danielsoper.com/statcal c3/calc.aspx?id=15
Uppal, H. S., Bal,i A, S. 1997. Quality of Basmoti rice kernel in relation to irrigation and planting dates. Journal of Reserch Panjab Agricultural University, 34: 251-258.

Yoshida, S., Forno, D. A., Cock, J. H., Gomez, K. A. 1976. Laboratory Manual for Physiological Studies of Rice, $3^{\text {rd }}$ ed., International Rice Research Institute, Manila, Philippines.

Younis, S. A., Al-Rawi, F. I., Hagor, E. G. 1990. Physiological and biochemical parameters of seed quality in some rice varieties (Oryza sativa L.). Seed Research, 18: 148-153. 